Autor:

\title{
Elimar Szaniawski
}

Título

\section{Os direitos de personalidade e sua tutela}

Banca Examinadora:

Presidente: Dr. Altino Portugal Soares Pereira

Dr. Gaspar Luiz Lacerda Pinto

Dr. Aloisio Surgik

Defesa: $\quad 18$ de dezembro de 1989.

\section{Resumo}

Os direitos de personalidade consistem nos atributos da personalidade situados como direitos primeiros do ser humano. $\mathrm{O}$ trabalho analisa a tutela destes direitos primeiros, detendo-se, especialmente, no estudo do confronto destes direitos primeiros frente a outros direitos, também primeiros, que possuem igual peso na escala de valores, merecendo, portanto, idêntica proteção. Assim, necessário é, verificar-se a natureza, extensão e efeitos limitadores em relação a outros direitos fundamentais do ser humano, fixando-se sua atuação. Para a realização de tal tarefa é mister, primeiramente, estudar e elaborar uma teoria geral dos direitos de personalidade para depois se extrair seus efeitos limitadores em relação a outros direitos e os limites que estes impõem sobre aqueles, em cada caso concreto dentro da ponderação de bens e interesses,, a fim de se poder alcançar o equilíbrio entre os diversos direitos e se obter a almejada justiça. 